\title{
Kiemelkedő erdélyi fizikusok
}

\section{Gábos Zoltán}

\begin{abstract}
Outstanding Transylvanian Physicists - In the present work we follow the history of the Transylvanian physics school from the beginning of the second millennium up to the year 1919. In the considered period the most important results of physics were obtained in Europe. In the first part of the presentation these results are briefly overviewed. The second part is focused on the scientific life in Transylvania during this period, studying the activity of peoples and institutions devoted to sciences. We particularly discuss the important results obtained in adopting and further developing the new results in physics.
\end{abstract}

A mikro-, makro- és kozmikus világ titkait fürkésző mai fizikus a jövőbe néz, az elötte álló nehéz feladatok megoldására összpontosít. De nyugalmasabb óráiban, amikor további munkájához erőt gyủjt, a múltat idézi, példaképeket keres, és elismeréssel gondol azokra, akik előtte jártak. Most is ezt tesszük. Olyan kiemelkedő személyiségekre emlékezünk, akiknek fontos szerepük volt az erdélyi fizika ápolásában, alakításában és gazdagításában.

A fizika az anyagi világ legáltalánosabb tulajdonságait és legátfogóbb törvényeit kutatja. A természettudomány része, a technikai haladás egyik meghatározó tényezője. Müvelése, gyakorlati haszna és tudatformáló ereje miatt fontos társadalmi tevékenység. Folyamatos bővülésének hajtóeröi körében még fontos szerepet játszik az emberi kíváncsiság, az ismeretlen kísértése és az alkotás igénye. A természettudomány egységes, részei közé nem emelhető merev válaszfal. Erre a fizika esetében a fizikai kémia, biofizika, geofizika, asztrofizika elnevezések is utalnak. A fizika a filozófiához és matematikához is szorosan kapcsolódik. Ez természetes, hiszen a filozófia az emberi gondolkodás és a megismerés terén érvényesülö legáltalánosabb törvényszerüségeknek a tudománya, a matematika pedig a fizikus számára az eszköz és nyelv szerepét tölti be.

A fizika terebélyesedése nem akadálymentes folyamat. Ennek emberi és társadalmi okai vannak. 
Általános emberi tulajdonság a megszokotthoz, a régihez való ragaszkodás. Az új eredmények és eszmék térhódítása még az egyazon tudomány művelőinek körében is ellenállásba ütközik. Valahányszor a hatalom sem érdekelt az új befogadásában, és a közösségen is kevés az újat igénylök számaránya, ez a helyzet még kihangsúlyozottabbá válik.

A tudománymủvelés a társadalomtól anyagi áldozatot követel, ezért döntő jelentősége van annak, hogy a közösség mennyit tud fordítani az iskolák, a kutatóintézetek, a tudományos egyesületek, a könyvtárak, a könyvés folyóirat-kiadás támogatására.

A tudományművelés nyugodt, békés körülményeket igényel. Ezért a történelmi eseményeket is a tudománymüvelést befolyásoló tényezők körébe kell sorolnunk.

A felsorolt tényezők eltérő mértékben érvényesültek a különböző országokban, esetleg országrészekben. Ha azt vizsgáljuk, hogy az országok milyen mértékben járultak hozzá az ismertek gyarapításához és mennyi időre volt szükségük az új ismeretek befogadására, igen színes kép alakul ki.

A következőkben az erdélyi fizika útját követjük a második évezred elejétöl 1919-ig. A figyelembe vett korszakban a fizika jelentős eredményei Európában születtek. Ezért az erdélyi fizikát ebben a keretben kell elhelyeznünk.

\section{Az európai fizika fejlődésének föbb állomásai}

Az ókorban a világról alkotott képet a közvetlen szemlélődésre, az elsődleges megfigyelésekre alapozták. Az eredmények összefoglalására elsőként a görög gondolkodók vállalkoztak. A viszonylag szegényes tapasztalati anyag tág teret hagyott az elmélkedésnek, a gondolkodásnak. Arkhimédész és mások azt is felismerték, hogy a matematika a fizikának hatásos eszköze. A görög gondolkodók érdeklődése mindenre kiterjedt. Például a görög tudományban jól megfért egymás mellett a ptolemaioszi geocentrikus és az arisztarkhoszi heliocentrikus világmodell, avagy a végtelenségig osztható arisztotelészi és a szemcsés (atomos) szerkezetü démokritoszi anyagmodell. Ekkor a fizika szoros kapcsolatban volt a különböző filozófiai irányzatokkal. 
Az V. századtól gyökeres változás következett be. A sokszínü görög filozófiát új filozófiai irányzat váltotta fel, a skolasztika. A skolasztika a megcsonkított és a teológiához igazított görög tudományt dogmává merevítette. A fizika terén előbb Platón, majd Arisztotelész eredményeiből válogattak. Mindez a fizika fejlődését károsan befolyásolta. A teológiát szolgáló filozófia keretében a fizikának szükös hely jutott. Elvetették a gondolkodás szabadságát és szentesítettek több helytelen felfogást. Ezek közül csak kettőt említünk. A mozdulatlannak tekintett Földnek szánták a világ középpontjának szerepét. Élesen elkülönítették a tökéletesnek vélt égi és a változó, tökéletlennek minősített földi világot.

Több mint félezer évnyi megtorpanás után kezdett jelentkezni a változtatás igénye. A megújulásban nagy szerepe volt a XII. századtól alakuló nyugat-európai egyetemeknek. Jogaiba visszahelyezték az arisztotelészi fizikát, a XIII. század második felében Nyugat-Európa egyetemein már a hamisítatlan arisztotelészi fizikát tanították. A XIV. században a megújulás két központjában, Párizsban és Oxfordban, az arisztotelészitől eltérő egyes ókori elképzelésekből is válogattak. Jean Buridan, a párizsi egyetem tanára, a század közepén cáfolta azt az arisztotelészi állitást, mely szerint a mozgás fenntartásához erőre van szükség. Ugyanebben az időben Nicole d’Oresme felhívta a figyelmet arra, hogy minden megfigyelő csak a relatív mozgást tudja észlelni, következésképpen a Föld forgásával kapcsolatban két lehetőség adódik: a csillagos égbolt forog a nyugalomban lévö Föld körül, vagy a Föld forog tengelye körül. Ö ez utóbbi lehetőséget tartotta helyesnek. Mások elvi szempontból bíráltak és az elörehaladást gátló tényekre hívták fel a figyelmet. Roger Bacon (1214-1294) angol filozófus, ferencrendi szerzetes sürgette, hogy a természet kutatásának alapja ne a tekintély, hanem a tapasztalat legyen. Azt is állította, hogy a tapasztalás mellett a matematikának kell a tudományos kutatás vezérfonalául szolgálni.

Roger Bacon eszméi megelözték korukat, elfeledkeztek róluk, így korának fizikájában nem hagytak nyomot. Két évszázad múltán Leonardo da Vinci (1452-1519) elevenítette fel a baconi gondolatot. Egyik kéziratában a következőket írta: „Ti tudósok ne bizzatok azokban a szerzökben, akik az ember és a természet között a képzelgések révén akarnak tolmácsok lenni, hanem csakis azokban, akik nem a természeti látszat, hanem a tapasztalatok eredményeivel müvelték ki elméjüket."

${ }^{1}$ Simonyi Károly: A fizika kultúrtörténete. Bp. 1978. 140. 
Az új fizika felé vezető úton az első forradalmi lépést Nikolausz Kopernikusz tette meg 1543-ban. Felelevenítve Arisztarkhosz heliocentrikus modelljét, a Földet megfosztotta központi szerepétöl és ezt a Nap bolygóinak körében iktatta. Ezzel rést ütött az égi és földi világ közé emelt válaszfalon. A fizika történetében új szakasz kezdődött, amelyik Isaac Newton főmüvének megjelenésével, az 1687-es évvel zárult.

A kopernikuszi modell térhódítását fékezte az, hogy Kopernikusz a bolygók pályáját egy bonyolult eljárással, körmozgásokból alakította ki. De ebben egy másik tény is szerepet játszott. A XVI. század első felében a katolikus egyház Európában elvesztette egyeduralmát, teret hódított a reformáció. A megosztottság a tudományművelés terén is jelentkezett. A katolikus egyház visszalépett, álláspontját megmerevítette. Úgy vélte, hogy a reformáció eredményességét az arisztotelészi tekintélyhez való merev ragaszkodással lehet ellensúlyozni. Ezzel akadályozták a fizika fejlődését, hiszen a kopernikuszi úton való elindulás eretnekségnek számított. A protestánsok bírálták és elvetették az arisztotelészi skolasztikát, Arisztotelész tekintélye helyébe a Biblia tekintélyét helyezték. Ezért ők sem részesítették Kopernikuszt kedvező fogadtatásban. Később azonban utat engedtek az elörelépést jelző Descartes-féle fizikának.

A Kopernikusztól Newtonig vezető utat egyengető személyiségek közül soroljuk fel a legismertebbeket.

A sikeres elörelépést segítette, hogy ebben a szakaszban alakultak ki a fizikai kutatás helyes módszerei. Francis Bacon angol filozófus Novum Organon címü 1620-ban megjelent mủvében hangsúlyozta, hogy a tapasztalat, a kísérletek, valamint az egyesböl az általánosra történő következtetési mód (indukció) révén kell eljutni a természet megismeréséig.

A kísérletezés szerepét a megismerésben elsőként Galileo Galilei (1564-1642) pontosította. Állította, hogy a kísérletekből, tapasztalatokból kiindulva, méréssel és a matematika felhasználásával állapítottunk meg természettörvényeket, amelyek helyességét kísérletekkel igazoljuk. Galileit tekintjük a kísérleti fizika igazi megalapozójának.

René Descartes 1637-ben és 1644-ben megjelent müveiben hangsúlyozta, hogy a természet kutatóinak meg kell adni a kételkedés jogát, mivel a kételkedés biztosítéka annak, hogy helyes következtetésekhez jutunk. Úgy vélte, hogy a biztos igazságok megtalálásának záloga a matematikában jól bevált módszer használata: alapigazságok (axiómák) segítségével, dedukció révén, a tapasztalati tények következményeként adódnak. Ezt a programot 


\section{EME}

elsőként Newton alkalmazta sikeresen, azért az elméleti fizika megjelenését Newtontól számítjuk.

A módszerek változatos bemutatása után néhány 1543 és 1687 között elért eredményt ismertetünk.

Johannes Kepler, a rendelkezésére álló gazdag megfigyelési adat birtokában, 1609-ben arra a következtetésre jutott, hogy a bolygók a Nap körül ellipszispályát írnak le.

Galilei 1610-ben négy, a Jupiter bolygó körül keringő holdat azonosított. Ezzel a heliocentrikus modell helyességét erösítette, hiszen a geocentrikus modellben az összes égi tárgyak a Föld körül végzik mozgásukat. Az egyház 1616-ban megtiltotta, hogy Galilei a Föld mozgásáról írjon, majd 1633-ban tanainak nyilvános visszavonására kényszerítették.

Galilei nagy érdeme, hogy 1638-ban megállapította a szabadesés törvényszerűségeit, amelyeket a helytelen arisztotelészi eredmények helyébe állitott.

Descartes megtörte az arisztotelészi fizika egyeduralmát. Eredményei köréből egy matematikai és egy fizikai jellegüt emelünk ki. Az analitikus geometria megalapozásával a fizika eszköztárát gazdagította. A világot egységes egésznek tekintette, annak tárgyait egyazon ősanyagból származtatta, miáltal a világnak földi és égi részre történő felosztása értelmét vesztette. A katolikus befolyás alatt álló intézmények a karteziánus fizikát nem fogadták be. Ez kezdetben még a protestáns intézményekben is akadályokba ütközött. Az utrechti egyetem szenátusa 1656-ban határozatban tiltotta el nemcsak a karteziánus tanok előadását, hanem a Descartes név említését is. A XVII. század végén azonban már minden nagyobb protestáns befolyás alatt álló egyetemen túlnyomórészt az ő fizikáját tanították.

Az új fizika kialakulásának terén a döntő lépést Newton tette meg. A fizikában elsőként alkalmazta sikerrel az axiomatikus módszert. Az 1687-ben megjelent Philosophiae Naturalis Principia Mathematica címü főmüvében olyan alaptörvényeket közölt, amelyekböl az ismert eredmények, például a bolygómozgás Kepler-féle, a szabadesés Galilei-féle törvényei következményként adódnak. Felismerte, hogy a szabadesést (egy „földi” mozgást) és a bolygók mozgását (egy „égi” mozgást) egyazon törvénnyel, az egyetemes tömegvonzás törvényével lehet magyarázni. Céljának megvalósítása érdekében a differenciál- és integrálszámítás megalapozásának feladatát is vállalta. 
Newton Principiájának megjelenésével lezárult a mintegy ezeréves küzdelem a skolasztikus gondolkodásmód ellen. Egyben új korszak is kezdődött, amely 1900-ig tart és a klasszikus fizika korszakának nevezzük. A XVIII. század elejétől teret hódított a Newton által megalapozott klasszikus mechanika. Oxfordban már 1700-tól newtoni mechanikát tanítottak. A protestáns intézményekben a newtoni tanok befogadását a karteziánus fizikához való ragaszkodás fékezte. A katolikus intézményekben a Galilei-féle tilalom feloldásával, 1757 után a newtoni mechanika is szabad utat kapott. Ezzel a fizika kiszabadult kettős alárendeltségéből. Megszabadult a teológia gyámságától és a filozófiából is kiválva, önálló szaktudománnyá érett. A mechanikában megvalósított sikeres szintézis termékenyítőleg hatott a fizika többi fejezetének művelőire.

1824 után a hőelmélet is a figyelme központjába került. A gőzgépek hatásfokának vizsgálata a hőtani fogalmak pontosításához és általános érvényü alaptörvények („főtételek”) megfogalmazásához vezettek. E folyamat felgyorsult, amikor a XIX. század közepétöl a fizikusok befogadták az 1808ban megfogalmazott daltoni atomhipotézist és a hőjelenségeket atomos és molekuláris alapon is magyarázták.

James Clerk Maxwell, Michael Faraday 1831-1856 között nyert eredményeire is támaszkodva, 1864-1873 között kidolgozta az elektromos és mágneses jelenségek egységes elméletét, az elektrodinamikát, amelybe a fény Christian Huygens által megalapozott hullámelmélete is belefért.

$\mathrm{Az}$ atomfelfogásra alapozó optikai vizsgálatok kémiai alapon is tanúsították a világ anyagi egységét.

A XX. században a fizika új, ún. modern szakaszába lépett. A klasszikus fizikát felváltó modern fizika két tartóoszlopon nyugszik, a relativitáselméleten és a kvantum-elméleten. Az eredmények ismertetése hosszúra nyúlna, ezért az általunk kitüzött célt követve csak az 1919-ig nyert eredményekből válogatunk. Az Albert Einstein által 1905-ben megalapozott speciális relativitáselmélet gyökeresen megváltoztatta a térrel és idővel kapcsolatos klasszikus felfogást. A klasszikus mechanikát a nagy sebességgel végbemenő mechanikai mozgások leírására is alkalmas relativisztikus mechanika váltotta fel. Az Einstein-féle általános relativitáselmélet (1915) a gravitációt új megvilágításba helyezte: leírására egy, a tömegek által meggörbített négydimenziós teret használunk. A kvantumelmélet 1900-ban jelent meg, amikor Max Planck felismerte, hogy az elektromágneses sugárzás energiája nem folytonosan, hanem adagokban változik. Einstein 1905-ben 
arra a következtetésre jutott, hogy az energiaadag hordozója egy sajátos részecske, a foton. Joseph John Thomson 1897-ben felfedezte az elektront. Ernst Rutherford a természetes radioaktiv anyagok szolgáltatta alfa részek segítségével 1911-ben felfedezte az atommagot, elsőként adott elfogadható atommodellt, majd 1919-ben végrehajtotta az első atommag-átalakítást. Niels Bohr 1913-ban közreadta a hidrogénatom, ma nevét viselö, kvantumelméletét, amelyet 1915-től Arnold Sommerfeld egészített ki.

\section{Az erdélyi fizika főbb állomásai}

A fizika ápolására Erdélyben az egyetemek, a főiskolai ranggal müködő oktatási intézmények és a tudományos tevékenység támogatását biztosító egyesületek vállalkoztak. Az oktatás és a tudományápolás szorosan egybefonódott.

Az erdélyi fizika történetének bemutatásakor mérföldköveket kell kijelölni. Egy elöző tanulmányunkban² olyan történelmi eseményeket vettünk alapul, amelyek az iskolák müködésében gyökeres változást eredményeztek. Most más utat követünk. Azt kívánjuk bemutatni, hogy milyen eredményeket értek el a fizika terén az oktatási intézmények, ezért fỏleg az alapítások és megszüntetések éveire fogunk alapozni.

A mohácsi vészig a Magyar Királysághoz tartozó Erdélynek nem volt egyetemi szintủ intézménye. Nagyvárad egyetlen fỏiskola jellegủ intézménye, az 1374-ben alapított káptalan iskola előképzést nyújtott a külföldön tanulni szándékozók számára. Fizikai ismeretekre társadalmi igény nem jelentkezett. Említésre méltó, hogy Vitéz János püspök 1455-ben Nagyváradon csillagvizsgálót létesített, amelyik 1472-ig müködött. Ekkor Mátyás király Esztergomba telepítette át.

Az erdélyi fizika szempontjából az első fontos lépést a Báthory István által 1581-ben alapított jezsuita egyetem kapunyitása jelentette. Az egyetem európai szintü fizikai képzést nyújtott. Bölcsészeti karán, a kétéves bölcsészeti tanfolyam keretében arisztotelészi fizikát tanítottak. A második évfolyamon a hallgatók a kinematika, dinamika, kozmográfia, hőtan és a cseppfolyós testek statikája köréből nyertek ismereteket. Az egyetem rövid életü volt, 1581 és 1588, valamint 1595 és 1603 között mủködött.

${ }^{2}$ Gábos Zoltán: Az erdélyi fizikusok hozzájárulása a magyar tudományhoz. Fizikai Szemle L. (2000). 117-124. 
Az erdélyi fizika szempontjából fontos szerepet játszott a Bethlen Gábor által 1622-ben alapított gyulafehérvári fỏiskola, a Collegium Bethlenianum. A Herbornból érkező neves tanár, Johann Heinrich Alsted 1629-től haláláig, 1638-ig szolgálta a főiskolát, ahol filozófiát tanított. Az enciklopédikus tudás híveként a természettudományok jelentőségét is hangsúlyozta. $\mathrm{Az}$ 1630-ban Herbornban kiadott Encyclopaedia septem Tomis distincta címü müvében arisztotelészi fizikát közvetített. Alsted 1629-ben magával hozta tanítványát, Johann Heinrich Bisterfeldet, aki a kollégiumban matematikát és természettudományokat oktatott. Bisterfeld az 1655-ig terjedő tevékenysége első éveiben arisztotelészi fizikát tanított, de később Arisztotelésztől távolodva egy „vallásos” fizikát alakított ki, miáltal egy sajátos protestáns skolasztika erdélyi képviselője lett. ${ }^{3} \mathrm{Ez}$ visszalépés jelentett, így a szükséges előrelépést nem o, hanem kiváló tanítványa, Apáczai Csere János tette meg.

Apáczai figyelmét az enciklopédikus tudás fontosságára kolozsvári kollégiumi tanára, Porcsalmi András hívta fel. Alsted példáját követve, hollandiai tanulmányútjának két évét főmüve, a Magyar Encyclopaedia megírására fordította. Az 1655-ben Utrechtben megjelent enciklopédiában saját eredményt nem közölt, ami természetes, hiszen Apáczai nem volt fizikus. De akkor egy fizikus számára miben áll e munka jelentősége? E kérdésre Apáczai maga felelt az enciklopédia címlapján talalható Seneca idézettel: „Ha a régiek mindent fel is fedeztek volna, mindenkor új lesz mégis a mások által felfedezettek használata, tudása és rendszerezése." Apáczai olyan, a haladás irányába mutató tudományos eredményeket közvetített az erdélyiek számára, amelyeket még a nyugati tudományosság sem fogadott el. Az ő korában ez merész és bátor tettnek számított. Két évtizeddel a Galilei-per után mert kopernikuszi tanokat hirdetni. Az is bátor tett volt részéről, hogy elfogadta a világ kialakulására vonatkozó, az arisztotelészi világrendet tagadó descartes-i elméletet. Descartes nem merte nyíltan vállalni a kopernikuszi heliocentrikus modellt. Öt túllépve Apáczai ezt is megtette, így ö volt az első erdélyi karteziánus, de az első erdélyi kopernikánus is.

A megismerés folyamatával kapcsolatban is haladó felfogást képviselt. Az 1653-ban elhangzott gyulafehérvári székfoglaló beszédében a következöket mondta: „A tudás, a megismerés kiindulópontja, forrása az érzékelés, a tapasztalat, akárcsak Baconnál és Comeniusnál. A megismerés elsö foka

\footnotetext{
${ }^{3}$ Marian, Victor - Popescu, Maria: Manuscrisele geometriei și fizicii lui J. H. Bisterfeld. Studia
} Universitatis Babeș-Boiyai, Physica 1. (1959). 161-177. 


\section{EME}

a tapasztalat, amelynek adatait az értelemnek kell feldolgoznia. A fizikai tudományokat a matematika kell hogy megelözze, mivel vele a természet minden jelensége kifejezhetö."

Az enciklopédia megjelenése más szempontból is fontos volt. Apáczai enciklopédiája az első magyar nyelvü ismerettár. Megjelenését egyik életcéljának tekintette, hiszen azt írta: „Nem halok meg addig, míg magyar nyelven nem közlöm a magyarokkal az összes tudományokat."Utat mutatott a magyar természettudományos szaknyelv megteremtése terén (egyes szóképzései ma is elfogadhatók). A természettudományok anyanyelven folyó oktatását szorgalmazó Apáczai művét tankönyvnek szánta. Könyvéről így nyilatkozott: „A magam és tanitványaim számára toldoztam ezt össze, nem mások számára."

Apáczai Gyulafehérváron 1653-ban elkezdett tevékenységét 1656-tól haláláig (1659-ig) a kolozsvári református kollégiumban folytatta. Három év már csak arra volt elég, hogy megírja a Phylosophia naturalis címủ 204 oldalas (kéziratban maradt) előadási jegyzetét.

Időközben a gyulafehérvári föiskola 1658-ban török büntetőhadjárat áldozata lett, így Erdély felsőfokú oktatási intézmény nélkül maradt. A helyzet 1698-ig nem változott. A következökben az 1658 és 1698 közötti megvalósításokból válogatunk.

A szemügyre vett időszakban a fizika szempontjából elörelépést jelentett az, hogy a karteziánizmus teret hódított. ${ }^{4}$ E tekintetben az 1662-ben alapított nagyenyedi Bethlen-kollégium tủnt ki. Előadási jegyzetek, doktori értekezések jelezték, hogy Apáczai számos követőre talált. Ezek közül csak néhányat említünk.

Enyedi Sándor nagyenyedi tanár 1666-os keltezésủ, tanítványa, Pápai Páriz Ferenc által leírt előadási jegyzete tanúsítja, hogy Enyedi karteziánus fizikát tanított.

Pápai Páriz Ferenc 1680 és 1717 között a nagyenyedi kollégiumban természettant is tanított. Rövid heidelbergi tartózkodása idején írta karteziánus fizikát közvetítő 1673-as keltezésü 49 oldalas Plenitudo vacui (A vákuum telítettsége) címü kéziratos munkáját. ${ }^{5}$

\footnotetext{
${ }^{4}$ Zemplén Jolán: A magyarországi fizika története 1711-ig. Bp. 1951; Marian, Victor: Introducerea fizicii lui Descartes în Transilvania. Studia Universitatis Babeş-Bolyai, series mathphys. fasc. 2 (1966). 75-81.

${ }^{5}$ Marian, Victor-Józsa János: Pápai Páriz Ferenc tudományos tevékenysége Heidelbergben. Fizikai Szemle XXI. (1971). 112-117.
} 
Köleséri Sámuel orvos és bányászati főfelügyelő minőségében jelentőset e területeken alkotott. De érdekelte a karteziánus fizika is, amit a hollandiai tanulmányútja idején Leydenben, 1681-ben kiadott Disputatio Mathematico Physica de Lumine címü kétrészes dolgozata is tanúsít. Köleséri az első magyar tudós, akit a londoni Royal Society 1729-ben tagjai körébe fogadott.

Továbbra is a tekintetbe vett időszaknál maradva az is említést érdemel, hogy a Sárospatakról 1671-ben elüzött tanárok új színt hoztak az erdélyi fizikába. Egy évi debreceni vendégeskedés után az üresen álló gyulafehérvári kollégiumban kaptak új otthont. Közülük Pósaházi János Comenius-tanítványt emeljük ki, aki haláláig (1686-ig) szolgálta Gyulafehérvárt. Philosophia naturalis címü fizikakönyvét 1667-ben Sárospatakon adta ki. A könyvből kitủnik, hogy a kor haladó fizikusainak (Galilei és mások) eredményeit ismerte. A mủ éles kritikai szelleméről is tanúskodik. Comeniustól a baconi empirizmus tiszteletét tanulta. Erdélyben ő hívta fel a fizikusok figyelmét arra, hogy a karteziánus fizika módosításra szorul. A világot folytonosan és hézagmentesen kitöltő "descartes-i”anyag helyébe az atomokat és vákuumot helyezte. Állította, hogy „inkább vagyok atomista mint tomista, inkább iszom Démokritosz tiszta forrásából, mint a skolasztikusok vagy arisztoteliánusok zavaros pocsolyájából". Az Apáczain túlmutató felfogása követőkre nem talált. Ez talán annak tulajdonítható, hogy a híres hitvitázóként számon tartott Pósaházi a karteziánus filozófia teológiai hatása ellen küzdött.

A Báthory-egyetem 1698-tól a jezsuita rend feloszlatásáig, 1773-ig folytathatta tevékenységét. Helyét az eredetileg felekezet nélkülinek szánt, de 1776-tól piarista kézbe került Mária Terézia-féle egyetem vette át. E rövid életü egyetemet II. József 1784-től megfosztotta egyetemi rangjától. A következőkben az 1698 és 1784 közötti szakasz megvalósításaiból válogatunk.

A katolikus irányítás alatt álló intézmények nem tértek le az arisztotelészi útról. Az egyetemen a XVIII. század közepéig a bölcseleti tanfolyam második évfolyamán az általános, részleges és kísérleti részekre osztott fizika keretében, arisztotelészi alapon az egyenes és görbe vonalú mozgások, világrendszer, fénytan, hőtan, elektromosság, cseppfolyós testek tana fejezeteket tanították. A XVIII. század közepén az állami beavatkozás ösztönzőleg hatott a fizika müvelésére. 1752-ben uralkodói rendelettel a Habsburg-birodalom területén müködő egyetemeket a bécsi egyetem mintájára 
szervezték át. Az elörelépésben Maximilian Höll (Hell Miksa) is segített, aki rövid, 1752 és 1755 közötti kolozsvári müködése alatt lakásán csillagdát állított fel és az intézetet felszerelte a kísérleti fizika legszükségesebb eszközeivel, ezzel is hangsúlyozva a kísérletezés fontosságát. 1757 után az egyetemen a Kopernikusz nevet is büntetlenül lehetett emliteni, jóllehet művét csak 1835-ben törölték a tiltott könyvek jegyzékéből. A katolikus középiskolákban a fizika oktatását az 1777-ben kiadott Ratio Educationis és annak erdélyi változata, a Norma Regia (1780) szellemében újjászervezték. A fizika a fakultatív tárgyak között szerepelt, csak a század végén került a kötelező tantárgyak sorába. Az arisztotelészi tanokhoz való merev ragaszkodást az új fizika felé való nyitás váltotta fel.

A protestáns iskolákban is jelentkeztek dogmatikus elemek, a XVIII. század első évtizedeiben megrekedtek a már túlhaladott karteziánus fizikánál. Ezt az abban az időben megjelent két fizikakönyv is tanúsítja. ${ }^{6}$

Szathmári Mihály marosvásárhelyi tanár 1719-ben Kolozsvárott jelentette meg karteziánus szellemben írt fizikakönyvét.

Tóke István nagyenyedi tanár 1736-ban Nagyszebenben kiadott latin nyelvü, több mint száz kísérletet bemutató könyvében elsőként kapcsolta egybe a fizika oktatását a kísérletekkel, a kísérletekhez azonban karteziánus magyarázatot füzött.

Galilei és Newton fizikája csak a XVIII. század második felében terjedt el általánosan Erdélyben. ${ }^{\top}$ Az új fizika befogadását segítette Nádudvari Sámuel marosvásárhelyi tanár, aki 1730 és 1740 között magyarra fordította Christian Wolff több mủvét. A filozófus sokat tett a newtoni elmélet népszerüsítéséért. A kolozsvári református kollégium két tanárának a kéziratai is jelezték az új fizika felé történő elmozdulást. Verestói György 1755ös keltezésü kéziratában Descartes és Newton eredményeiből válogatott. Pataki Sámuel, aki 1752-ben a leydeni egyetemre ment, ahol három évig gyarapította ismereteit a fizika tanulásával, 1760-as keltezésű kéziratában a newtoni elméletre alapozott. A református kollégiumok számára 1769-ben kiadott tantervben a fizika a filozófiától leválasztott tárgyként szerepelt. A tanterv gyakorlatba ültetését segítette 1774-ben Kováts József nagyenyedi tanár azzal, hogy németböl latinra fordította Johann Krüger Naturlehre címü könyvét, amelyben a kísérletek newtoni magyarázatot kaptak. Foga-

${ }^{6}$ Zemplén Jolán: A magyarországi fizika története a XVIII. században. Bp., 1964.

${ }^{7}$ Marian, Victor: Introducerea mecanicii lui Newton în România. Studia Universitatis BabeșBolyai, series math-phys., fasc. 1/1967. 79-83. 
rasi Pap József az erő fogalmának legtágabb értelmezéséről írt dolgozatával 1778-ban megnyerte a berlini Tudományos Akadémia 50 arannyal jutalmazott pályázatát. Ez is tanúsítja, hogy az ő idejében Marosvásárhelyen newtoni fizikát tanítottak.

Erdélyben 1784 és 1872 között nem működött egyetem. Ez visszaesést eredményezett, hiszen az egyetem akkor szünt meg, amikor mind a katolikus, mind a protestáns intézményekben az új fizika gyökeret vert. Jóllehet Erdélynek nem volt egyeteme, a föiskolai ranggal müködő iskolák, a kolozsvári, marosvásárhelyi, nagyenyedi református kollégiumok, a kolozsvári katolikus líceum, a kolozsvári unitárius kollégium, részben pótolni tudták a hiányzó egyetemet. Ezekben az intézményekben a hatosztályos gimnáziumi képzést egy kétéves föiskolai tanfolyam egészitette ki. A főiskolai képzés feladatát általában külföldön járt professzorok látták el.

Az egyetem hiányának káros következményeit enyhítette, hogy több vonatkozásban kedvező változások történtek. Megvalósult Apáczai álma, 1840 körül a középiskolákban a természettudományokat már magyar nyelven tanították.

Tudományos igényeket is kielégítő könyvtárakat alapítottak, megalakultak az erők összefogását szolgáló első tudós társaságok. Ezek közül a fizika szempontjából az 1811-ben alapított marosvásárhelyi Teleki-könyvtár és a Mikó Imre által 1859-ben alapított Erdélyi Múzeum-Egyesület jutott fontos szerephez.

Új eredmények elérésének és a magas szinten folyó fizikaoktatás igénye is jelentkezett. E vonatkozásban első sorban Bolyai Farkas, Bolyai János és Méhes Sámuel nevét kell említenünk.

Bolyai Farkas jénai és göttingai tanulmányútját követően 1804 és 1851 között a marosvásárhelyi kollégium matematika-, fizika- és kémiaprofesszora volt. Kétkötetes, Tentamen címü, 1832-ben és 1833-ban kiadott müvében a fizikus is talál új meglátásokat. Például elsőként hívta fel a figyelmet arra, hogy a nem euklidészi geometriák létjogát a bolygók mozgásában mutatkozó rendellenességek vizsgálatával lehetne igazolni. Ma a bolygók mozgásában jelentkező, a newtoni elmélet alapján nem magyarázható perihéliumelmozdulás az általános relativitáselmélet legismertebb kísérleti támasza. A Magyar Tudós Társaság Bolyai Farkast 1832-ben levelező tagja körébe fogadta.

Méhes Sámuel 1809 és 1845 között a kolozsvári református kollégium matematika-fizika tanára volt. Kinevezése elött három éven át Heidelberg- 
ben tanult. Két kéziratot hagyott hátra. Az első, 1807-es keltezésü Philosophiae Naturalis Methaphysica címü kéziratát nem fejezte be. A valamivel később íródott Physica címü 300 oldalas kézirata elsö részének a Physica generalis, második részének a Physica specialis címet adta. Az egyetemi jegyzetek és más források alapján összeállított kézirat, a korabeli értékelés szerint, valamennyi magyar nyelvterületen megjelent fizikakönyvet felülmúlta mind terjedelemre, mind tudományos tartalomra nézve. Megjelenése esetén a munka a föiskolai tankönyv és a hasznos kézikönyv szerepét egyaránt betölthette volna. Méhest a Magyar Tudós Társaság 1836-ban levelező tagjává választotta.

$\mathrm{Az}$ erdélyi matematika legkiemelkedőbb személyisége Bolyai János. A geometria terén elért eredményeivel a fizikának is nagy szolgálatot tett. Olyan eszközt adott a fizikusok kezébe, amelynek bővített változatai fontos szerepet kaptak az Einstein-féle gravitációelméletben. Ö és Nyikolaj Ivanovics Lobacsevszkij elsőként hívták fel a figyelmet arra, hogy a newtoni gravitációelmélet javításra szorul. Geometriájukra alapozva egy új gravitációs erötörvényt is adtak.

Az erdélyi tudományosság történetének kiemelkedő eseménye volt a kolozsvári egyetem 1872. évi kapunyitása. Ez több szempontból is gyökeres változásokat hozott.

$\mathrm{Az}$ állami egyetem egyenlő esélyeket biztosított az összes vallásfelekezetü diáknak. Az oktatás nyelve a magyar volt. Az indulással járó nehézségek leküzdése után az egyetem a kor színvonalán álló oktatói és tudományos tevékenységet végzett. A tudomány gazdagítására is vállalkozó egyetemen keresztül Erdély intézményesen is bekapcsolódott a világ tudományos hálózatába. Az egyetem a természettudományok jelentőségét azzal is tanúsította, hogy külön Matematikai és Természettudomány Kart létesített (abban az időben Európában ilyen kar csak a tübingeni egyetemen müködött). Az Erdélyi Múzeum-Egyesület 1879 és 1905 között a kar tanárainak lehetőséget nyújtott arra, hogy az egyesület szakülésein és népszerủ tudományos estélyein bemutatott dolgozataikat az egyesület által fenntartott Orvos- és Természettudományi Értesítőben közöljék. ${ }^{8}$ Az egyetem az országos folyóiratok és társulások felé is nyitott. A fizikusok számos tanulmányt jelentettek meg a Matematikai Természettudományos Értesítóben, a Matematikai

\footnotetext{
${ }^{8}$ Balogh Ernő: A természettudományi szakosztály története. = Az Erdélyi Múzeum-Egyesület háromnegyedszázados tudományos müködése 1859-1934. Szerk. György Lajos. Kvár, 1937. $37-88$.
} 
és Fizikai Lapokban, és tevékeny részt vállaltak az 1891-ben alakult Matematikai és Physikai Társulat munkájából. Fontosabb eredményeiket neves külföldi folyóiratokban is közölték. Az első magyar nyelven oktató erdélyi egyetem szerepet vállalt a magyar tudományos szaknyelv gazdagításában, egyetemi jegyzetek és könyvek kiadását vállalva.

Az egyetem két fizikai tanszékkel indult, a kísérleti természettan és a mennyiségtani természettan tanszékekkel. 1904-ben egy gyakorlati fizikai és elektrotechnikai tanszéket is létesítettek. A következőkben ezek eredményeiböl válogatunk. ${ }^{9}$

Abt Antal, a kísérleti fizika első professzora Kolozsváron mágnességtani iskolát alapított. Utóda, Tangl Károly kolozsvári müködése idején (1903-1917) a gázok dielektromos állandóját mérte magas nyomásokon és a vízploatinarétegrendszer esetében a felületi feszültséget a rétegvastagság függvényében elemezte. Tangl munkatársai közül többen is kiváló eredményeket értek el. Ortvay Rudolf, aki nála szerzett doktori címet, a folyadékok dielektromos állandóját mérte magas nyomásokon. Gyulai Zoltán szelénen végzett fényelektromos vizsgálatokat. Pogány Béla vékony fémrétegek elektromos vezetöképességét és optikai sajátosságait tanulmányozta a rétegvastagság függvényében. 1917 után a tanszékvezetői feladatokat Pogány látta el.

Pfeiffer Péter 1884 és 1902 között Abt Antal tanársegédje volt. 1904ben számára egy új, gyakorlati fizikai és elektrotechnikai tanszéket létesítettek. Pfeiffer az elektromágneses hullámok terjedésének vizsgálata terén ért el értékes eredményeket.

Az elméleti fizika (mennyiségtani természettan) tanári állását az egyetem indulásakor nem tudták betölteni. Két év múltán Kolozsvárra küldték a Heidelbergből hazatérő Réthy Mórt, aki 1884-ig képviselte a kolozsvári elméleti fizikát. Kolozsvári tartózkodása idejében hőtani, fénytani és hidrodinamikai kérdésekkel foglalkozott. Sokat tett a Bolyai-hagyományok ápolása terén. 1884-töl 1887-ig (Farkas Gyula érkezéséig) az átmenetet a matematikus Vályi Gyula biztosította. Farkas Gyula, a kolozsvári elméleti fizika kimagasló képviselője, 1915-ig (nyugdíjba vonulásáig) szolgálta a kolozsvári egyetemet. Európai szintre emelte a kolozsvári elméleti fizikát. Több területen ért el értékes eredményeket. Ezek közül hármat emelünk ki. Használhatóvá tette a mechanikai kényszermozgásokra vonatkozó, elfelejtett

\footnotetext{
9 Gábos Zoltán: A fizika Kolozsváron. = Fejezetek a magyar fizika elmúlt 100 esztendejéböl (1891-1991). Szerk: Kovács László. Bp., 1992. 207-216.
} 
Fourier-elvet. Az ehhez szükséges matematikai eszköztárat maga dolgozta ki. Eredményét 1950 óta az optimalizálás elméletével foglalkozó matematikusok is sikerrel hasznosítják. 1895-ben elsőként közelített modern alapon az entrópia-fogalomhoz. Két évvel a speciális relativitás-elmélet megjelenése után, amikor sok neves tudományos központ még kétkedve fogadta az új elméletet, Farkas Gyula e tárgykörből egyetemi előadást tartott, később az elmélet gazdagítására is vállalkozott. A páduai egyetem 1892-ben díszdoktorrá avatta. Nála szerzett doktori címet a ma csak zeneszerzőként ismert Kacsóh Pongrác. Nyugdíjba vonulása után Ortvay Rudolfot bízták meg a tanszék vezetésével. Ortvay előzőleg ösztöndíjasként néhány hónapot Zürichben Peter Debye, majd két évet Münchenben Arnold Sommerfeld mellett dolgozott. Az 1919-ig terjedő rövid idő számára csak arra volt elég, hogy külföldi tapasztalatait az oktatás terén hasznosítsa.

A fizika terén elért eredmények bemutatása nem lenne teljes, ha nem emlékeznének Károly Iréneusz Józsefre és Martin Lajosra.

Károly Iréneusz József 1907-ben nyert magántanári képesítést az elektromos sugárzás kísérleti tanának köréből. A drótnélküli távírás egyik úttörője. Drótnélküli távírójával 1895 áprilisában 20 méterre, valamivel később a Premontrei Főgimnázium laboratóriumából a tíz kilométerre levő peceszentmártoni rendházba tudott morzejeleket továbbítani. Vele egyidőben Giuglielmo Marconi és Alekszandr Sztepanovics Popov ért el hasonló eredményeket. Róla megfeledkeztek, mivel szélesebb körben nem tudósított megvalósításáról. Egy évvel a röntgensugárzás felfedezése után a fögimnáziumban oktatói, gyógyászati és tudományos célokat szolgáló röntgenlaboratóriumot létesített, amelyik 1896. december 12-én kezdte el müködését.

Martin Lajos a felsőbb matematika professzora a repülés elméleti és gyakorlati kérdéseivel kapcsolatban végzett úttörő munkásságot. Lebegő kerekére 1893-ban osztrák szabadalmat kapott.

Berde Áron, az egyetem első rektora az 1872. november 10-én tartott beiktatási beszédében a következőket mondta: „Kétségbe kellene esnem a harmadik kolozsvári tudományegyetem küszöbénél, ha elöre hinném, hogy a történelmi tények oly következetesen ismétlik útjokat, mint a bolygók napjaink körül és hogy azt elödei sorsa fenyegeti." Ma már tudjuk, hogy a sejtés nem volt alaptalan. 1919-ben a Ferenc József Tudományegyetem bezárta kapuit. Ezzel az erdélyi egyetem és így az erdélyi fizika történetében is egy megvalósításokban gazdag időszakasz zárult le. 


\section{Következtetések}

Az elöbbiek alapján állíthatjuk, hogy ami a fizikát illeti, Erdély 1872-ig a tudomány peremvidékeihez tartozott. Általában csak pár évtizedes késéssel fogadta be az élenjáró országok által nyújtott tudományos eredményeket és haladó eszméket. Ez első pillanatra furcsának tünik, hiszen a tanulni vágyó erdélyi ifjak viszonylag sürủn látogatták a külföldi egyetemeket. A látszólagos ellentmondás okait keresve több fejlődést gátló tényezőt találunk.

Erdélynek nem volt folyamatosan müködő egyeteme, tehát a tudományos tevékenység folytonossága nem volt megoldva. A mohácsi vésztől 1919-ig eltelt 393 év alatt Erdélynek mindössze 148 évig volt egyeteme. Így egyes időszakokban az eredmények befogadása, közvetítése, az értelmiségi utánpótlás kinevelése intézményesen nem volt biztosítva.

Nagy nehézségbe ütközött a magasabb kulturális és gazdasági szinten álló országokban szerzett ismereteknek és eszméknek Erdélybe történő átültetése. Erdély hosszú ideig nem volt érett azok befogadására. A tudományukkal hazatérő fiatalokat sokszor elismerés helyett részvétlenség, közöny, meg nem értés és nem egyszer a hatalom gáncsoskodása fogadta. Hosszú ideig a világi értelmiség alacsony számaránya is gátló tényezőként jelentkezett.

Az erdélyi tudós más szempontból is hátrányos helyzetben volt. Nyugat-Európában a XVII. századtól számos, a tudományos tevékenységet egybefogó és támogató akadémia alakult. Tudós társaságok jöttek létre (a Royal Society 1660-ban, az Académie des Sciences 1666-ban), tudományos folyóiratok indultak. Mindez az erdélyi tudós számára csak mintegy két évszázad múltán valósulhatott meg. A Magyar Tudós Társaság és az Erdélyi Múzeum-Egyesület megalakulásáig az erdélyi természettudósok egymástól elszigetelt, meg nem értett, magányos küzdők voltak. Erdélyben csak 1879től indult, az Erdélyi Múzeum-Egyesület jóvoltából, tudományos igényeket kielégítő természettudományos folyóirat.

$\mathrm{Az}$ eredmények felsorolásából az is kiderül, hogy nagyon sok a kéziratban maradt munka. A szerzők saját eredményeiket, meglátásaikat is a kéziratokban rejtették el. A nyomtatott könyvek kis száma főleg azzal magyarázható, hogy azokat a szerző csak saját költségén adhatta ki. A könyvnyomtatást nem a szerény jövedelmű erdélyi tanárok számára fedezték fel.

A tanulmányút után a hazatérőnek csak szük lehetősége volt a további kapcsolattartásra. Ez azzal a súlyos következménnyel járt, hogy a külföldről 


\section{EME}

hazahozott információs anyag birtokában nyert eredményeikről a tudományos világ nem szerzett tudomást.

Az egyes időszakokban a felsorolt gátló tényezők különböző mértékben érvényesültek. Ezeket az időszakokat egyes kiemelkedő személyiségei esetében mutatjuk be.

A sort Apáczai Csere Jánossal kezdjük. Az 1653-ban hazatérő Apáczai természettudományos ismereteire a gyulafehérvári föiskolának nem volt szüksége. Művét itthon teljes részvétlenség és közöny fogadta. Bisterfeld 1655-beli halála után nem foglalhatta el az őt megillető professzori állást. Haladó, az egyházi életet is érintő jobbító szándékú javaslataival is korán érkezett, ezért 1656-ban Kolozsvárra számüzték. Apáczai követői is, a XVIII. század elejéig ellenállásba ütköztek. Abban az évben, amikor Pápai Páriz Ferenc Heidelbergben dolgozatát megírta, itthon a radnóti zsinaton a karteziánusok és a protestáns skolasztikusok közötti vita ez utóbbiak javára dőlt el. Pápai Páriz Ferenc külföldön nyíltan is vállalta karteziánus elkötelezettségét, itthon felfogását csak burkoltan, Descartes nevének elhallgatásával tudta közölni.

Bolyai Farkas, aki göttingai tanulmányútja idején Karl Friedrich Gauss barátja és egyenrangú társa volt, hazatérte után nem matematikával, hanem négy éven át kertészettel foglalkozott, addig a marosvásárhelyi kollégium nem tartott igényt tapasztalataira. A tudományos központoktól távol, a külföldtöl csaknem teljesen elszakítva a saját költségén kiadott könyvében ismertette saját eredményeit. Ilyen körülmények között a könyvben elrejtett eredményei nem számíthattak külföldi elismerésre. De a hazai elismerés is elmaradt. Bolyai Farkas 1836-ban elkeseredetten írta Gaussnak: „Müvemet makulatúrára használom, csomagolásra és más effélékre."

Bolyai János 1831-ben külön füzetben, majd apja könyvében, a függelékben közölte hiperbolikus geometriáját. Az önmagát kínzó és emésztő Bolyai János domáldi, majd marosvásárhelyi magányában hiába várta a megérdemelt elismerést. Tudományos kérdésekben csak apjával értekezhetett, információs anyagot csak a Teleki-könyvtárban, valamint apja (és személyes) könyvtárában kaphatott. Gauss, aki öt Gerlinghez írt levelében elsőrangú lángésznek tartotta, egy barátságos vállveregetésen kívül semmit sem tett azért, hogy barátjának fiát a tudományos világnak bemutassa. A kazányi egyetem tanárának, az államtanácsosnak Gauss sokkal többet nyújtott, mint a nyugalmazott császári kapitánynak. Lobacsevszkijt Gauss 1843-ban a göttingai Tudós Társaság tagjává választotta és attól is megkí- 


\section{EME}

mélte, hogy Bolyai János müvéröl tudomást szerezzen. Bolyai Jánosról a tudományos világ csak akkor vett tudomást, amikor 1859-től kezdve megjelentették Gauss levelezését, és az Appendixet 1867-ben francia, majd 1868-ban olasz nyelvre lefordították. Ma az Appendix tíz nyelven olvasható. $\mathrm{Az}$ itthoni elismerés is elmaradt. A Magyar Tudós Társaság fö feladatának a magyar nyelv kiművelését tekintette, és nem ismerte fel Bolyai János „új világának" jelentőségét. Döbrentei Gábor, a társaság fötitkára a következöket írta Bolyai Farkasnak: „Fiadra a Kapitányra nézve is az a barátságos észrevételem van, hogy ha magyarul adja ki munkáját, lehet új helybeli tag is ..." A latin nyelvủ Appendix magyar fordítása 1897-ben jelent meg.

A fentiek az 1872-ig terjedö korszakra vonatkoznak. Ismertetésünkből is kiderült, 1872 után a helyzet gyökeresen megváltozott. Az 1919-ig terjedő időszakban a tevékenységet az indulás nehézségei, majd 1914-től a háborúval járó káros következmények gátolták. 